\title{
PENGARUH PROFITABILITAS DAN SOLVABILITAS TERHADAP HARGA SAHAM PADA EMITEN SEKTOR PROPERRTY DAN REAL ESTATE DI BURSA EFEK INDONESIA
}

\author{
Umar Faruk, Egie Selamet Aprian
}

\begin{abstract}
ABSTRAK
Penelitian ini bertujuan untuk mengetahui: (1) gambaran profitabilitas emiten sektor property dan real estate di BEl tahun 2010, (2) gambaran solvabilitas emiten sektor property dan real estate di BEI tahun 2010, (3) gambaran harga saham emiten sektor property dan real estate di BEl tahun 2011, (4) pengaruh profitabilitas terhadap harga saham saham pada emiten sektor property dan real estate di BEI tahun 2011, (5) pengaruh solvabilitas terhadap harga saham pada emiten sektor property dan real estate di BEI tahun 2011 dan (6) pengaruh profitabilitas dan solvabilitas terhadap harga saham pada emiten sektor property dan real estate di BEI tahun 2011. Profitabilitas diukur melalui Return on Assets (ROA), dan solvabilitas diukur menggunakan Debt to Equity Ratio (DER). Metode penelitian yang digunakan adalah metode deskriptif verifikatif. Sampel penelitian ini adalah seluruh emiten property dan real estate yang terdaftar di BEI serta aktif menerbitkan laporan keuangan selama tahun pengamatan, yaitu sebanyak 40 emiten. Pengumpulan data dilakukan dengan cara mengambil dokumentasi laporan keuangan dari BEI dan diolah menggunakan uji statistik regresi linier berganda. Berdasarkan hasil penelitian dapat diketahui: (1) secara umum profitabilitas sektor property dan real estate memiliki nilai ROA yang rendah, oleh karena itu harus bisa lebih meningkatkan kinerja, sehingga memperoleh laba yang tinggi, (2) secara umum solvabilitas perusahaan sektor property dan real estate masih terdapat beberapa perusahaan yang memiliki hutang yang tinggi sehingga memiliki rata-rata yang tinggi,(3) secara umum harga saham sektor property dan real estate masih masih rendah karena masih terdapat perusahaan yang memiliki harga saham dibawah rata-rata sektoral, (4) profitabilitas berpengaruh positif terhadap harga saham pada sektor property dan real estate tahun 2011, (5) Solvabilitas tidak berpengaruh terhadapa harga saham pada sektor property dan real estate dan (6) profitabilitas dan solvabilitas berpengaruh terhadap harga saham pada emiten sektor property dan real estate.
\end{abstract}

Kata Kunci: Sektor Property dan Real Estate, Profitabilitas (ROA), Solvabilitas (DER) dan Harga Saham.

\section{Pendahuluan}

Harga saham merupakan harga yang terjadi di pasar bursa pada saat tertentu yang ditentukan oleh pelaku pasar dan ditentukan oleh permintaan dan penawaran saham yang bersangkutan di pasar modal. Harga suatu saham akan cenderung naik bila suatu saham mengalami kelebihan permintaan dan cenderung turun jika terjadi kelebihan penawaran.

Dari aktivitas pasar modal harga saham merupakan faktor yang sangat penting dan harus diperhatikan oleh investor dalam melakukan investasi karena harga saham menunjukkan prestasi 
emiten. Pergerakan harga saham searah dengan kinerja emiten, apabila emiten mempunyai prestasi yang semakin baik maka keuntungan yang dapat dihasilkan dari operasi usaha semakin besar. Oleh karena itu, setiap perusahaan yang menerbitkan saham sangat memperhatikan harga sahamnya. Harga yang terlalu rendah sering diartikan bahwa kinerja perusahaan kurang baik.

Pasar modal menawarkan banyak sekali pilihan kepada investor untuk menanamkan modalnya. Salah satu saham yang bisa memberikan penawaran yang menarik adalah saham di bidang property dan real estate. Sahamsaham di bidang property dan real estate menjadi menarik karena prospek bisnis dari perusahaanperusahaan tersebut cukup meyakinkan. Hal ini dikarenakan harga tanah cenderung naik tiap tahunnya, penyebabnya adalah supply tanah bersifat tetap sedangkan demand akan selalu besar seiring pertambahan penduduk. Kenaikan yang terjadi pada harga tanah diperkirakan $20 \%$, selain itu tanah bersifat rigrid, artinya penentu harga bukanlah pasar tetapi orang yang menguasai tanah. Dalam bakriglobal.com tanggal 11 juni 2011, Ahmad Sujatmiko analis PT. Pemeringkat Efek Indonesia (Pefindo) menyatakan 'saham sektor properti masih menarik karena pendapatan masyarakat Indonesia terus meningkat yang akan mempengaruhi permintaan hunian perumahan.'

Berdasarkan uraian diatas, seharusnya harga saham di bidang property dan real estate dapat maksimal. Namun bila dilihat perkembangan harga saham dan volume perdagangan setiap tahunnya bisa dikatakan kurang menarik banyak investor. Hal ini dapat terlihat dari data perkembangan indeks harga saham dan volume sektoral property dan real estate di BEI periode 20062011, yang disajikan dalam tabel 1.1 , sebagai berikut.

Tabel 1

Perkembangan Indeks Harga Saham dan volume

\begin{tabular}{|l|l|l|}
\hline \multirow{2}{*}{ Periode } & \multicolumn{2}{|l|}{$\begin{array}{l}\text { Property dan Real } \\
\text { Estate }\end{array}$} \\
\cline { 2 - 3 } & Harga & Volume \\
\hline 2009 & 122,93 & - \\
\hline 2010 & 251,82 & 154.209 .023 .690 \\
\hline 2011 & 103,49 & 107.727 .377 .907 \\
\hline 2012 & 146,80 & 197.508 .425 .489 \\
\hline 2013 & 199,96 & 265.469 .901 .758 \\
\hline 2014 & - & 215.146 .899 .310 \\
\hline
\end{tabular}

Berdasarkan tabel 1.1 perkembangan harga saham selama periode 2009-2014 dalam sektor property dan real estate mengalami fluktuasi. Perusahaan mengalami kenaikan harga saham dari tahun 2009 ke tahun 2010 sebesar 105\%. Pada tahun 2011 harga saham property dan real estate mengalami penurunan yang signifikan sebesar $59 \%$ dan mengalami kenaikan kembali sebesar $42 \%$ pada tahun 2012, dan 36\% pada tahun 2013.

$\begin{array}{clr}\text { Bila harga saham naik } & \text { nam } \\ \text { dengan } & \text { volume } & \text { menurun }\end{array}$ kemungkinan koreksi tajam dalam waktu dekat sangat mungkin terjadi, karena volume transaksi dapat digunakan sebagai alat untuk menganalisa pergerakan saham pada kondisi normal, saat harga saham naik, volume transaksi juga meningkat. Harga saham yang kurang maksimal dengan volume 
penjualan yang menurun maka dapat mengurangi kepercayaan investor terhadap investasi yang ditanamkan di dalam perusahaan. Mereka dapat merubah keputusannya untuk berinvestasi di perusahaan tersebut dan mencari perusahaan lain untuk menanamkan modalnya agar memperoleh keuntungan yang tinggi atas saham yang dimiliki.

\section{Landasan Teori}

\section{Pergerakan harga saham} pada umumnya dipengaruhi beberapa faktor sesuai dengan pendapat Natarsyah (2000:296) yang menyatakan bahwa, "Faktorfaktor yang mempengaruhi tingkat pergerakan harga saham yaitu faktor eksternal dan internal." Faktor eksternal atau tekhnikal yaitu untuk mempelajari tentang prilaku pasar yang diterjemahkan kedalam grafik riwayat harga dengan tujuan untuk memprediksi harga di masa yang akan datang. Sedangkan faktor internal atau faktor fundamental adalah studi tentang ekonomi, industri dan kondisi perusahaan untuk memperhitungkan nilai dari saham perusahaan. Faktor fundamental menitikberatkan pada data-data kunci dalam laporan keuangan untuk memperhitungkan apakah harga saham sudah diapresiasi secara akurat.

Dari faktor-faktor tersebut, dapat dikatakan faktor fundamental merupakan faktor yang penting dan berpengaruh terhadap harga saham. Bagi pemegang saham faktor tersebut memberikan gambaran yang jelas dan bersifat analisis terhadap prestasi manajemen perusahaan dalam mengelola perusahaan yang menjadi tanggung jawabnya. Oleh karena itu, dalam Penelitian ini menekankan pada faktor fundamental perusahaan dari aspek kinerja keuangan yang bersifat controllable. Alat yang biasa digunakan untuk menilai kondisi dan kinerja keuangan perusahaan adalah hasil rasio keuangan. Rasiorasio keuangan yang umumnya digunakan adalah rasio likuiditas, rasio solvabilitas, rasio aktivitas, rasio profitabilitas dan rasio pasar.

Menurt Arifin, A. (2002:82) diungkapkan bahwa, "Saham yang baik untuk dibeli adalah saham yang perusahaannya untung." Investor dalam melakukan keputusan investasinya akan lebih menekankan pada kemampuan perusahaan dalam menghasilkan laba dan efisiensi operasinya. Demikian juga dengan para calon pemegang saham yang menanamkan modalnya dalam bentuk saham biasa akan lebih tertarik terhadap profitabilitasnya.

Informasi profitabilitas sangat diperlukan bagi investor, karena profitabilitas berkaitan dengan harga saham dan dividen perusahaan, sehingga dapat diperoleh informasi tentang jumlah laba yang dapat diperoleh dari investasi yang telah ditanam. Ketika investor membeli saham berarti investor sedang menyuntikkan dana segar ke perusahaan tersebut. Akibatnya, modal perusahaan tersebut bertambah. Jika modal bertambah tapi kemampuannya dalam mencetak laba tidak meningkat maka pasti ada sesuatu yang ganjil. Hal inilah yang mesti diperhatikan oleh setiap investor dalam melakukan investasi. Karena itulah rasio profitabilitas perusahaan digunakan untuk menakar seberapa besar kemampuan perusahaan mencetak laba.

Selain profitabilitas, ukuran kinerja keuangan perusahaan 
adalah rasio solvabilitas. Rasio ini merupakan gambaran bagi para pengguna laporan keuangan untuk mengetahui komposisi kekuatan equity perusahaan yang memberi batasan keamanan terhadap tingkat utang yang dimiliki perusahaan. Oleh karena itu, investor sangat perlu mengetahui tingkat penggunaan hutang dalam suatu perusahaan sebelum menanamkan dananya pada perusahaan yang diinginkan. Apabila tingkat hutang semakin tinggi berarti semakin besar pula beban bunga sehingga mengurangi keuntungan perusahaan. Hal ini sesuai dengan pendapat Arifin, A. (2002:82) mejelaskan bahwa, "Selain kemampuan perusahaan mencetak laba, harus diperhatikan juga kemampuan perusahaan tersebut bertahan hidup, kemampuan membayar hutang/solvabilitas."

Pemilihan faktor-faktor di
atas sebagai variabel bebas
didasarkan pemikiran bahwa faktor
tersebut menggambarkan resiko dan
return yang akan diterima para
pemodal atas investasinya pada
saham perusahaan. Meskipun
terdapat faktor lain yang bersifat
teknikal berpengaruh terhadap
kekuatan pasar, akan tetapi faktor
yang bersifat fundamental ini akan
menjadi pedoman utama bagi pasar
untuk menentukan harga saham
perusahaan.

\section{Metode Penelitian}

Metode yang akan digunakan dalam penelitian ini adalah metode deskriptif dan verifikatif.

\section{a. Populasi dan Sampel}

Populasi dalam penelitian ini adalah perusahaan atau emiten pada Bursa Efek Indonesia dengan karakteristik tertentu, Kriteria populasi yang akan di ambil dalam penelitian ini adalah :

1. Perusahaan yang menjadi populasi termasuk kedalam emiten sektor Property dan Real Estate.

2. Perusahaan terus listing di Bursa Efek Indonesia sampai pada tahun 2011.

Laporan keuangan dipublikasikan dan lengkap. Berdasarkan ketiga karakteristik tersebut

$$
\text { populasi dalam penelitian }
$$

adalah berjumlah 40 sehingga sampel penelitian ini menggunakan sampel jenuh atau sensus. Menurut Sugiyono (2010:124), yang dimaksud dengan sampel jenuh atau sensus adalah "teknik penentuan sampel bila semua anggota populasi digunakan sebagai sampel."

\section{b. Teknik Analisis Data}

Analisis data merupakan salah satu tahap kegiatan penelitian berupa proses penyusunan dan pengolahan data guna menafsirkan data yang telah diperoleh dari lapangan. Untuk mengetahui pengaruh dari variabel independen profitabilitas dan solvabilitas terhadap variabel dependen harga saham, data tersebut penulis melakukan pengolahan data dengan langkah-langkah ini :

1. Mendapatkan data-data yang berkaitan dengan penelitian, penelitian ini menggunakan cross sectional atau mengnalisi laporan keuangan semua perusahaan Property dan Real Estate pada tahun 2010.

2. Menganalisis laporan keuangan tahun 2010 menggunakan profitabilitas, dicari menggunakan rumus :

$$
\begin{aligned}
& \text { Return on Asset } \\
& =\frac{\text { Laba Bersih }}{\text { Total Aktiva }} \times 100 \%
\end{aligned}
$$


(Mamduh M.H, 2007:159)

Sedangkan untuk DER dapat dicari dengan menggunakan rumus :

Debt to Equity Ratio

$=\frac{\text { Total Hutang }}{\text { Total Ekuitas }} \times 100 \%$

(Mamduh M.H, 2007:155)

3. Analisis harga saham setelah dipublikasikan

laporan

keuangan tahun 2011.

Sebelum melakukan analisis data dengan menggunakan model regresi linier berganda, terlebih dahulu dilakukan uji asumsi klasik. Pengujian asumsi klasik diperlukan untuk mengetahui apakah hasil estimasi regresi yang dilakukan benar-benar terbebas dari adanya gejala heterokedastisitas, gejala multikolinearitas, dan gejala autokorelasi (Hasan, I. 2009:282). Dalam penelitian ini uji asumsi klasik yang digunakan adalah sebagai berikut.

1. Tidak ada multikolinieritas

2. Tidak terjadi heteroskedastisitas

3. Uji Linieritas

Persamaan regresi linier berganda harus memenuhi persyaratan BLUE (Best, Linear, Unbiased, Estimator), yaitu pangambilan keputusan melalui uji $F$ dan uji t tidak boleh bias. Untuk mendapatkan hasil yang BLUE, maka harus dilakukan pengujian asumsi klasik di bawah ini:

Uji multikolinieritas adalah keadaan dimana pada model regresi tidak ditemukan adanya korelasi yang sempurna atau mendekati sempurna antar variabel independen. Pada model regresi yang baik seharusnya tidak terjadi korelasi yang sempurna atau mendekati sempurna diantara varibel bebas (korelasinya 1 atau mendekati 1). Beberapa nilai
Tolarance dan Inflation Factor (VIF) pada model regresi atau dengan membandingkan nilai koefesien determinasi individual $\left(r^{2}\right)$ dengan nilai determinasi serentak $\left(R^{2}\right)$. Berikut uji multikolenieritas yang dilakukan :

1. Dengan melihat nilai tolerance dan inflation factor (VIF) pada model regresi

Untuk mengetahui suatu model regresi bebas dari multikolinearitas, yaitu mempunyai nilai VIF $<10$ dan mempunyai angka tolarence > 10.

2. Dengan membandingkan nilai koefesien determinasi individua $\left(r^{2}\right)$ dengan determinasi secara serentak $\left(R^{2}\right)$.

Dalam metode ini cara yang ditempuh adalah dengan meregresikan setiap variabel independen dengan variabel independen lainnya, dengan tujuan mengetahui nilai koefesien $r^{2}$ untuk setiap varibel yang diregresikan. Selanjutnya nilai $r^{2}$ tersebut dibandingkan dengan nilai koefesien determinasi $R^{2}$. Kriteria pengujiannya yaitu $r^{2}>R^{2}$ maka terjadi multikolinieritas dan jika $r^{2}<R^{2} \quad$ maka tidak terjadi multikolenieritas.

Heteroskedastisitas

menunjukkan bahwa varians variabel tidak sama untuk semua pengamatan jika varians dari residual satu pengamatan ke pengamatan yang lain tetap, maka disebut homokedastisitas. Model regresi yang baik adalah yang homokedastisitas atau tidak terjadi heteroskedastisitas.

Salah satu cara untuk melihat adanya heteroskedastisitas adalah dengan menggunakan program SPSS, dengan melihat grafik scatterplot antara nilai prediksi variabel terikat (ZPRED) dengan 
residualnya (SRESID). Cara menganalisisnya :

1. Jika ada pola-pola tertentu, seperti titik-titik yang ada membentuk suatu pola tertentu yang teratur (bergelombang kemudian menyempit), maka terjadi heteroskedastisitas

2. Jika ada pola yang jelas, seperti titik-titik menyebar di atas dan di bawah angka 0 pada sumbu $Y$, maka tidak terjadi heteroskedastisitas.

Linearitas merupakan keadaan dimana hubungan antara variabel terikat dengan variabel bebas bersifat linear (garis lurus) dalam range variabel bebas tertentu. Menurut Siagian dan Sugiarto (2006:225), "Untuk memberikan gambaran hubungan dua variabel, sebelum mengetahui apakah berhubungan linear atau tidak sebaiknya dilakukan plotting (tebaran titik) terhadap pasangan nilai-nilai $X$ dan $Y$. Hasil plot ini disebut dengan diagram pencar (scatter diagram)". Jika terdapat gejala bahwa letak titik-titik data itu menyebar disekitar garis lurus maka antara kedua variabel terdapat hubungan linear, maka uji regresi dapat dilanjutkan. Sebaliknya jika titik-titik data itu tidak berada disekitar garis lurus, maka antara kedua variabel tersebut tidak terdapat hubungan linear, maka uji regresi tidak dapat dilanjutkan.

\section{c. Pengujian Hipotesis}

Uji regresi linier berganda adalah alat analisis nilai pengaruh dua variabel bebas atau lebih terhadap satu variabel terikat atau dengan kata lain untuk membuktikan ada atau tidaknya hubungan antara dua variabel bebas atau lebih dengan satu variabel terikat.

Persamaan regresi linier berganda dalam penelitian ini adalah sebagai berikut.

$$
\widehat{Y}=a+b_{1} X_{1}+b_{2} X_{2}
$$

(Riduwan, 2011 : 253)

Keterangan :

$\widehat{Y}=$ Variabel $Y$ (Harga Saham)

$\alpha=$ Konstanta yang merupakan nilai variabel $Y$ pada saat nilai variabel $X_{1}$ dan $X_{2} 0$ (nol)

$b_{1} b_{2}=$ Koefesien Regresi

$X_{1} \quad=$ Profitabilitas

$X_{2} \quad=$ Solvabilitas

Analisis regresi berganda dalam penelitian ini dilakukan dengan menggunakan software SPSS V 16 for windows.

Uji signifikansi $F$ dilakukan untuk mengetahui apakah secara bersama-sama variabel independen berpengaruh signifikan terhadap variabel dependen. Sedangkan untuk menentukan $\mathrm{F}$ tabel dapat dilihat pada tabel statistik pada tingkat signifikansi 0,05 dengan df 1 (jumlah variabel), df 2 (n-k-1) dengan $n$ adalah jumlah data dan $k$ adalah jumlah variabel independen. Rumus yang digunakan untuk uji $\mathrm{F}$ ini adalah sebagai berikut.

$$
F=\frac{J K(\operatorname{Reg}) / k}{J K(S) /(n-k-1)}
$$

(Sudjana, 2003:91)

Keterangan :

$J K(R e g)=b_{1} \sum x_{1} y+b_{2} \sum x_{2} y+\ldots+$ $b_{3} \sum x_{3} y$

$J K(S)=\Sigma y^{2}-J K(\operatorname{Reg})$

Kriteria pengujiannya adalah sebagai berikut.

1. $F_{\text {hitung }}>F_{\text {tabel }}$ atau nilai sig < taraf signifikansi 0,05 maka Ho ditolak dan $\mathrm{H}_{1}$ diterima, artinya Profitabilitas dan Solvabilitas berpengaruh terhadap harga saham. 
2. $F_{\text {hitung }} \leq F_{\text {tabel }}$ nilai sig $>$ taraf signifikansi 0,05 maka Ho diterima dan $\mathrm{H}_{1}$ ditolak. artinya Profitabilitas dan Solvabilitas tidak berpengaruh terhadap harga saham.

Pengujian ini dimaksudkan untuk mengetahui keberartian koefisien yang telah diperoleh dengan menggunakan rumus uji $\mathrm{t}$. Pengujian ini bertujuan untuk melihat apakah profitabilitas dan solvabilitas berpengaruh signifikan terhadap harga saham property dan real estate, atau dengan kata lain untuk menguji keberartian model regresi yang didapat. Pengujian ini diperoleh melalui rumus :

$$
t=\frac{b}{S b}
$$

(Sudjana, $2003:$ 31)

Keterangan :

b = koefisien regresi

$\mathrm{Sb}=$ kesalahan baku koefisien regresi berganda $b$

Dalam pengujian hipotesis melaui uji $\mathrm{t}$ ini, tingkat kesalahan yang digunakan peneliti adalah $5 \%$ atau 0.05 pada taraf signifikan $95 \%$. Pengujian t-statistik bertujuan untuk menguji signifikansi variabel independen dalam mempengaruhi variabel dependen. Pengujian tstatistik ini merupakan uji dua pihak. Adapun kriteria pengambilan keputusan untuk hipotesis yang diajukan adalah sebagai berikut.

$\mathrm{H}_{0}$ diterima dan $\mathrm{H}_{\mathrm{a}}$ ditolak bila $t_{\text {tabel }} \leq t_{\text {hitung }} \leq t_{\text {tabel }}$

bila $t_{\text {hitung }} \geq t_{\text {tabel }}$

$\mathrm{H}_{\mathrm{a}}$ ditolak dan $\mathrm{Ha}$ diterima

Hipotesis yang akan diujikan dalam penelitian ini adalah :

$H_{0}: \beta_{1}=0$, Profitabilitas tidak berpengaruh terhadap harga saham Property dan Real Estate.
$H_{1}: \beta_{1} \neq 0, \quad$ Profitabilitas berpengaruh terhadap harga saham Property dan Real Estate.

$H_{0}: \beta_{2}=0$, Solvabilitas tidak berpengaruh terhadap harga saham Property dan Real Estate.

$H_{1} \quad: \quad \beta_{2} \neq 0, \quad$ Solvabilitas berpengaruh terhadap harga saham Property dan Real Estate.

$H_{0}: \beta_{1}=\beta_{2}=0$, Profitabilitas dan solvabilitas tidak berpengaruh terhadap harga saham property dan real estate.

$\mathrm{H}_{1}$ : Tidak Semua $\beta_{i}=0$, Profitabilitas dan solvabilitas berpengaruh terhadap harga saham property dan real estate.

\section{Hasil dan Pembahasan}

\begin{tabular}{llr}
\multicolumn{2}{c}{ Dengan analisa kinerja } \\
keuangan ini dapat & $\begin{array}{r}\text { diketahui } \\
\text { kekuatan dan }\end{array}$ kelemahan \\
perusahaan di bidang & keuangan. \\
Perusahaan yang & melakukan
\end{tabular} penjualan kepada masyarakat bertujuan untuk keberlangsungan perusahaan itu sendiri. Untuk menarik investor, perusahaan harus mampu menunjukkan kinerjanya. Pengukuran kinerja dapat dilakukan menggunakan rasio keuangan. Harga saham merupakan salah satu indikator keberhasilan pengelolaan perusahaan. Harga saham senantiasa bergerak dan pergerakan tersebut ditentukan oleh kekuatan permintaan dan penawaran saham itu sendiri di pasar modal. Bagi investor, harga saham mencerminkan nilai suatu perusahaan.

Penelitian ini bertujuan untuk mengetahui pengaruh profitabilitas dan solvabilitas terhadap harga saham pada perusahaan sektor property dan real estate yang terdaftar di Bursa Efek Indonesia. 
Dalam penelitian ini profitabilitas dapat dilihat dari return on assets dan solvabilitas dilihat dari debt to equity ratio. Standar yaang digunakan untuk profitabilitas dan solvabilitas menggunakan rata-rata emiten sektor property dan real estate, hal ini sama dengan yang di ungkapkan oleh Widoatmodjo $\mathrm{S}$. (180:2009), "Tidak semua rasio memiliki standar dalam teori atau memiliki patokan, hal ini bisa menggunakan rata-rata industri, atau data historis perusahaan".

\section{Pengaruh Profitabilitas Terhadap Harga Saham}

Profitabilitas adalah

kemampuan perusahaan dalam menghasilkan laba, dalam penelitian ini profitabilitas dihitung menggunakan rasio Return on Assets (ROA) adalah perbandingan antara laba bersih setelah pajak dengan total aktiva. Berdasarkan hasil penelitian, nilai ROA sektor property dan real estate periode 2010 menunjukan masih banyak perusahaan yang mempunyai nilai ROA dibawah rata-rata return on assets sektoral, yaitu sebanyak 24 perusahaan atau $60 \%$ dari 40 perusahaan. Artinya sektor property dan real estate rata-rata masih rendah dalam menghasilkan laba dan dalam penelitian ini juga menunjukan bahwa ada 8 perusahaan yang memperoleh nilai return on assets negatif, hal ini disebabkan karena perusahaan tersebut mencatatakan kerugian. Kerugian ini disebabkan adanya penurunan pendapatan, bertambahnya biaya operasional perusahaan sehingga berpengaruh terhadap nilai ROA.

Berdasarkan hasil pengujian hipotesis hasil analisis regresi linier berganda diperoleh nilai konstanta harga saham (variabel Y) sebesar
238,008 dan koefisien pemanfaatan profitabilitas $\left(\beta_{1}\right)$ sebesar 7940,312 . Dari nilai koefisien regresi yang positif tersebut menunjukkan adanya pengaruh positif antara profitabilitas terhadap harga saham property dan real estate di BEI. Hal ini berarti, setiap adanya peningkatan profitabilitas maka akan meningkatkan harga saham property dan real estate di BEI. Kemudian berdasarkan perhitungan uji hipotesis uji t, didapatkan nilai sig < dari taraf signifikansi atau $0,000<$ 0,025 , hasil $t$ hitung $>t$ tabel, yakni $4,785>2,026$ maka Ho ditolak dan $\mathrm{H}_{1}$ diterima, yang menunjukan bahwa "Profitabilitas berpengaruh positif terhadap harga saham."

Artinya semakin besar ROA semakin besar tingkat keuntungan yang dicapai perusahaan. Ini menunjukan bahwa manajemen dapat menggunakan berdasarkan data laporan keuangan total aktiva perusahaan dengan baik (aktiva lancar dan aktiva tetap) dan pada akhirnya akan meningkatkan harga saham perusahaan sehingga menarik banyak investor untuk menanamkan modalnya di perusahaan property dan real estate. Hal ini sesuai dengan teori yang dinyatakan oleh Husnan, $S$ dan Pudjiastuti (2006:317), "Jika kemampuan untuk menghasilkan laba meningkat, harga saham akan meningkat dengan kata lain profitabilitas akan meningkatkan harga saham."

$$
\text { Hasil penelitian ini juga }
$$
sejalan dengan penelitian yang dilakukan oleh Sukmayanda, Y. (2012) dengan judul Pengaruh Profitabilitas Terhadap Harga Saham PT. Bank Internasional Tbk. Bahwa profitabilitas mempunyai pengaruh terhadap harga saham. 


\section{Pengaruh Solvabilitas Terhadap Harga Saham}

Hasil penelitian selanjutnya yaitu solvabilitas terhadap harga saham sektor property dan real estate di Bursa Efek Indonesia dengan indikator debt to equity ratio menunjukan bahwa sektor property dan real estate memiliki rata-rata debt to equity ratio sebesar 0,75205 atau $75 \%$. kondisi ini menunjukan bahwa sebagian besar perusahaan dalam kondisi kurang baik. Hal ini dibuktikan dari 40 perusahaan terdapat $47,5 \%$ perusahaan mempunyai debt to equity ratio lebih dari rata-rata sektoral.

PT. Duta Anggada Realty Tbk. (DART), merupakan perusahaan yang memiliki rasio paling tinggi dan PT. Panca Wiratama Sakti Tbk. (PWSI) yang memiliki ekuitas negatif, sedangkan PT. Citra Kebun Raya Agri Tbk. (CKRA) adalah perusahaan yang memiliki DER negatif.

Berdasarkan hasil pengujian hipotesis hasil analisis regresi linier berganda diperoleh nilai konstanta harga saham (variabel $Y$ ) sebesar 238,008 dan koefisien pemanfaatan profitabilitas $\left(\beta_{1}\right)$ sebesar (103.829). Dari nilai koefisien regresi yang negatif tersebut menunjukkan adanya pengaruh negatif antara solvabilitas terhadap harga saham property dan real estate di BEI. Hal ini berarti, setiap adanya penurunan solvabilitas maka akan meningkatkan harga saham property dan real estate di BEI. Kemudian berdasarkan perhitungan uji hipotesis uji t, didapat nilai sig $>$ dari taraf signifikansi atau 0,353 >0,025, hasil t hitung $<\mathrm{t}$ tabel, yakni $-0,940<$ 2,026 maka $\mathrm{Ho}$ diterima dan $\mathrm{H}_{1}$ ditolak, yang menunjukan bahwa "Solvabilitas tidak berpengaruh terhadap harga saham pada emiten sektor property dan real estate di BEI."

Debt to Equity Ratio merupakan kemampuan perusahaan dalam memenuhi kewajibankewajibannya dengan melalui modal sendiri yang dimiliki oleh perusahaan tersebut. Setiap perusahaan yang go public tidak semuanya mempunyai modal sendiri yang cukup besar untuk menutupi seluruh kewajiban yang ada sehingga perusahaanperusahaan tersebut membutuhkan modal asing dari para investor. Dengan semakin tingginya modal asing dari para investor hal ini akan meningkatkan resiko perusahaan terhadap hutang tersebut. Dan dalam sektor property dan real estate merupakan perusahaan yang bersifat jangka panjang sehingga membutuhkan modal yang cukup banyak tidak sama halnya dengan perusahaan di bidang konsumsi yang mempunyai perputaran yang sangat cepat.

$$
\text { penelitian ini bahwa }
$$

Solvabilitas tidak berpengaruh terhadap harga saham sektor property dan real estate hal ini disebabkan data dalam penelitian ini hanya menggunakan data satu tahun sedangkan dalam penelitian sebelumnya menggunakan banyak tahun sehingga data yang diteliti tidak cukup memberikan bukti untuk menerima hipotesis penelitian. Penggunan indikator DER saja tidak cukup dalam meneliti solvabilitas dalam pengaruhnya terhadap harga saham sektor property dan real estate, karena masih banyak faktor lain yang lebih potensial dalam mempengaruhi harga saham, melihat hal tersebut, menjadi hal yang perlu digarisbawahi agar menjadi pertimbangan tersendiri untuk melakukan penelitian dengan topik yang sama bagi peneliti selanjutnya. 


\section{Pengaruh Profitabilitas dan Solvabilitas Terhadap Harga Saham}

Berdasarkan hasil pengujian hipotesis menggunakan uji $F$ diperoleh nilai $F_{\text {hitung }} 11.591$ dengan nilai (sig) 0,000, dari hasil uji $F$ diperoleh $F_{\text {hitung }}$ lebih besar dari $F_{\text {tabel }}$ yakni $11.591>3,248$ dan nilai sig < dari nilai probabilitas yakni $0,000<$ 0,05 , hal ini menunjukkan bahwa profitabilitas dan solvabilitas berpengaruh terhadap harga saham pada emiten sektor property dan real estate di $\mathrm{BEI}$, artinya bahwa $\mathrm{H}_{1}$ diterima sedangkan $\mathrm{H}_{0}$ ditolak.

Dari pembahasan diatas dan berdasarkan pengujian hipotesis dapat disimpulkan bahwa profitabilitas dan solvabilitas berpengaruh terhadap harga saham. Profitabilitas merupakan hal yang penting untuk diperhatikan bagi para manajer keuagan dalam meningkatkan kinerja keuangan perusahaan terutama untuk meningkatkan laba perusahaan sehingga akan berdampak pada kepercayaan investor untuk menanamkan modalnya dan pada akhirnya meningkatkan harga saham. Sedangkan solvabilitas adalah kemampuan perusahaan dalam membayar kewajibannya, suatu perusahaan dapat dikatakan sovable apabila perusahaan tersebut telah mampu membayar semua kewajibannya dengan aktiva yang dimilikinya. Sehingga profitabilitas dan solvabilitas sangatlah penting bagi perusahaan untuk diperhatikan, khususnya solvabilitas tidak bisa secara parsial untuk mengetahui ada tidaknya pengaruh terhadap harga saham property dan real estate akan tetapi harus secara bersama dengan profitabilitas. Hal ini sependapat dengan yang diungkapkan oleh Widoatmodjo S. (178:2009), bahwa "Untuk mengetahui perusahaan yang sehat, maka ukuran yang biasa digunakan adalah profitabilitas, likuiditas dan solvabilitas" dan mendukung penelitian sebelumnya yang dilakukan oleh Bernard C. (2012) dengan judul "Pengaruh Profitabilitas Dan Solvabilitas Terhadap Harga Saham Pada PT. Tambang Batubara Bukit Asam, Tbk. Di Bursa Efek Indonesia". Hasil penelitian tersebut menyebutkan bahwa secara simultan profitabilitas dan solvabilitas berpengaruh terhadap harga saham.

Pada intinya kinerja yang baik akan menimbulkan hal yang positif dimata investor, sehingga investor akan menanamkan modalnya dan perusahaan akan mendaptkan modal yang cukup untuk mendanai perusahaan, melakukan ekspansi, dan mendapatkan keuntungan bagi perusahaan maupun investor.

\section{Kesimpulan dan Saran}

Dari hasil penelitian dan pembahasan data yang ada, maka penulis dapat manarik kesimpulan sebagai berikut:

1. Profitabilitas (ROA) pada sektor property dan real estate di Bursa Efek Indonesia periode 2013 dari 40 perusahaan terdapat 24 perusahaan yang memiliki ROA dibawah rata-rata sektoral. Sebanyak 8 perusahaan yang memiliki nilai laba bersih negatif. Nilai return on assets paling tinggi terdapat di PT. Roda VivaTex Tbk. (RDTX), sedangkan nilai ROA paling rendah diperoleh pada perusahaan PT. Citra Kebun Raya (CKRA). Hal ini membuktikan perusashaan di sektor ini masih randah dalam menghasilkan laba, oleh karena itu harus bisa lebih 
meningkatkan kinerja, sehingga memperoleh laba yang tinggi.

2. Solvabilitas (DER) pada sektor property dan real estate di bursa efek indonesia periode 2013 secara keselurahan memiliki rata-rata yang cukup tinggi, karena masih banyak perusahaan sebagian besar pendanaan proyek pengembangan bertumpu pada hutang. PT. Duta Anggada Realty Tbk. (DART) merupakan perusahaan yang memiliki nilai debt to equity ratio paling tinggi dan PT. Panca Wiratama Sakti Tbk. (PWSI) memiliki jumlah ekuitas negatif sekaligus memiliki nilai paling rendah.

3. Harga saham perusahaan property dan real estate periode 2011 di Bursa Efek Indonesia menunjukan dari 40 perusahaan terdapat 27 perusahaan yang memiliki nilai harga saham dibawah rata-rata harga saham sektoral. Hal tersebut menunjukan bahwa harga saham property dan real estate masih rendah dibandingkan perusahaan property dan real estate lainnya. Harga saham tertinggi diperoleh PT. Metropolitan Kentjana Tbk. (MKPI), sedangkan untuk harga saham terendah terdapat di dua perusahaan yaitu pada PT. Bhuwanatala Indah Permai Tbk. (BIPP) dan PT. Laguna Cipta Griya Tbk. (LCGP).

4. Berdasarkan hasil analisis statistik menggunakan analisis regresi berganda menunjukan bahwa secara parsial profitabilitas berpengaruh positif terhadap harga saham pada emiten sektor property dan real estate tahun 2014 di BEl. Artinya setiap terjadi kenaikan nilai profitabilitas akan diiringi dengan kenaikan harga saham.

5. Untuk solvabilitas dengan menggunakan analisis statistik regresi berganda akhirnya didapatkan kesimpulan bahwa solvabilitas secara parsial tidak berpengaruh terhadap harga saham pada emiten sektor property dan real estate tahun 2014 di BEl. Artinya walaupun terjadi kenaikan atau penurunan nilai solvabilitas maka harga saham cenderung tidak mengalami perubahan.

6. Dari hasil uji F, Profitabilitas dan solvabilitas berpengaruh terhadap harga saham pada emiten sektor property dan real estate tahun 2011 di BEI.

\section{Saran}

Sebagai tindak lanjut atas kesimpulan penelitian di atas, maka penulis mengajukan saran antara lain sebgai berikut.

1. Semua perusahaan sektor property dan real estate diharapkan mampu mempertahankan labanya karena laba perusahaan selalu menjadi fokus perhatian para investor dalam memutuskan untuk berinvestasi. Karena laba menjadi ukuran kinerja manajemen perusahaan. Semakin tinggi nilai profitabilitas maka investor akan tertarik untuk menananmkan modalnya sehingga harga saham meningkat.

2. Analisis kinerja keuangan dengan menggunakan variabel solvabilitas tidak bisa berdiri sendiri untuk dijadikan sebagai dasar pengambilan keputusan berinvestasi saham. Khususnya saham sektor property dan real estate Sebaiknya para investor dapat menggunakan alat 
analisis kinerja lainnya seperti profitabilitas dan lainnya.

3. Bagi peneliti selanjutnya, analisis dalam penelitian ini masih terbatas pada satu sektoral saja yaitu sektor property dan realestate di Bursa Efek Indonesia. Fokus pembahasan hanya pada beberapa faktor fundamental yaitu profitabilitas dengan indikator return on aset dan solvabilitas dengan indikator debt to equity ratio, sehingga hasil interpretasi masih belum memberikan konklusi yang bersifat general, disarankan kepada peneliti lebih lanjut untuk memperluas bahasan.

\section{Daftar Pustaka}

Arifin, A. (2002). Membaca Saham. Yogyakarta: Andi.

Badan Pengawas Pasar Modal dan Lembaga Keuangan. (20062010). Statistik Pasar Modal. Jakarta: Bapepam-LK.Hasan, lqbal. (2002). Pokok-Pokok Materi Metodologi Penelitian dan Aplikasinya; Edisi Pertama. Jakarta: Ghalia Indonesia.

Fahmi, I. dan Lavianti, Y. (2009). Teori Prtofolio dan Analisis Investasi teori dan Soal Jawab. Cetakan kesatu. Alfabeta.

Harahap, S. (2008). Analisis Kritis Laporan Keuangan. Jakarta: Raja Grafindo Persada.

Hasan, I. (2009). Analisis Data Penelitian Dengan Statistik. Jakarta:Bumi Aksara.

Husnan, S. (2003). Dasar-dasar Teori Portofolio dan Analisis Sekuritas. Edisi Ketiga Yogyakarta : UUPP AMP YKPN.
Husnan, S dan Pudjiastuti E. (2006) Dasar-dasar Manajemen Keuangan. Edisi Lima Yogyakarta: UUPP STIM YKPN.

Horne, J.C. , dan Wachowiz, J.M. (2005). Financial Management. Jakarta: Salemba Empat.

Jumingan. (2006). Analisis Laporan Keuangan. Cetakan Pertama. Jakarta: Bumi Aksara.

Jogiyanto (2008). Teori Portofolio dan Analisis Investasi. Edisi kedua. Yogyakarta: Penerbit BPFE.

Kasmir. (2008). Analisis Laporan Keuangan. Jakarta: Rajawali Pers.

Mamduh, M.H. (2007). Analisis Laporan Keuangan Keuangan. Yogyakarta: UPP AMP YKPN.

Natarsyah (2000). Analisis Pengaruh

Beberapa Faktor Fundamental dan Risiko Sistematik TerhadAP

Harga Saham, Jurnal Ekonomi dan bisnis Indonesia, Vol. 15, No 3, Hal 294-312

Martalena dan malinda, M. (2011). Pengantar Pasar Modal. Yogyakarta: Andi.

Octavia, E. (2010). Pengaruh Faktor Fundamental Terhadap Harga Saham Sektor Makanan dan Minuman Di Bursa Efek Indonesia, Vol. 10 No. 2. Hal. 181-212.

Riduwan (2011). Dasar-dasar Statistika. Bandung: Alfabeta

Rusdin, (2008). Pasar Modal. Bandung: Alfabeta.

Sartono, A. (2008). Manajemen Keuangan Teori dan aplikasi. Edisi keempat. Yogyakarta: BPFE. 
Sawir, A. (2005). Analisis Kinerja Keuangan dan Perencanaan Keuangan. Jakarta: PT Gramedia Pustaka Utama.

Siagian dan Sugiarto, (2006). Metode Statistika Untuk Bisnis Dan Ekonomi. Jakarta: PT Gramedia Pustaka Utama.

Sudjana. (2003). Teknik Analisis Regresi dan Korelasi Bagi Para Peneliti. Bandung : Tarsito.

Sugiyono. (2010). Metode Penelitian Pendidikan. Bandung: Alfabeta.

. (2010). Statistik untuk Penelitian. Bandung: Alfabeta.

Sudiyatno, B.(2010). Pengaruh Kebijakan Perusahaan

Dengan

Kinerja
Perusahaan

Variabel Intervening. Semarang:

Dinamika Keuangan

dan

Perbankan, vol. 2, No. 1 Hal. 2.

Sukardi, D. dan Indonanjaya, K. (2010) Manajemen Investasi

Prndekatan Teknikal dan

Pendekatan Fundamental untuk

Analisis Saham. Yogyakarta:

Graha IImu.

Tim Pertimbangan Pembimbingan Skripsi. 2007. Pedoman Operasional Penulisan Skripsi. Bandung: Pendidikan Akuntansi.

Widoatmodjo, S. (2009). Pasar Modal Indonesia. Bogor: Ghalia Indonesia.

Wild, J. (2005). Analisis Laporan Keuangan. Jakarta: Salemba Empat. 